\title{
Improving Students' Speaking Skill Through the Use of Cooperative Script
}

\author{
Hamdan $^{1 *}$ \\ ${ }^{I}$ STKIP PGRI Lubuklinggau, Indonesia \\ *Corresponding author. Email: hamdangh123@gmail.com
}

\begin{abstract}
The study aims to improve the students' Speaking Skill to the eleventh grade of Madrasah Aliyah Tazakka Musi Rawas Utara. This study was formulated null hypothesis (Ho) and the alternative hypothesis (Ha). The population was all of the eleventh grade students and total number of sample was 24 students. The sample study was taken through cluster random sampling. In study used the quasi- experimental method. In collecting the data, The studi employed the pre-test - treatment -the post-test. Analyzing the data used individual score, conversion of individual score, normality test, hypothesis testing, and hyphotesis statistics. The finding revealed that in the pre-test, the students' average score was 56 and the post-test their average score increased to be 70 . The result of match t-test was 11.43 while $\mathrm{t}$-table was 1.714 . Therefore, Cooperative Script was significantly effective to improve speaking skill of the eleventh grade students of Madrasah Aliyah Tazakka Musi Rawas Utara
\end{abstract}

Keywords: Improving, Speaking, Cooperative Script, and Skill

\section{INTRODUCTION}

English is known as an International language. In Indonesia, English is studied as a foreign language. English has been considered as the most important language in the world. English is one of popular languages. It is used by many people to communicate each other's. English is the language used to communicate and exchange the information.

Communication is an important part of human civilization and it is a mean of cultural transformation. Communication can carry out either in spoken or written form. According to [1] , there are three reasons why people communicate. First, people communicate because they want to say something. Harmer explained, the world "want" refers to intentional desire the speaker has in order to convey massages to other people. Second, people communicate because they have some communicative purposes. The third reason is the consequence communicative activities.

As a foreign language, English is taught in Indonesian schools. It is learned from primary school even senior high school. English subject consists of four language skills, namely listening, speaking, reading and writing. Therefore, students should be better to master them. One of the objectives in teaching English is students are able to communicate in speaking English. By speaking, students can improve their skill in communicating to another and the students are able to express themselves orally.

Speaking is one of skills in English. According to [2], speaking is social in the sense that it establishes rapport and mutual agreement, maintains and modifies social identity, and involves interpersonalskills. This social element is expresses through wishes, feelings, attitudes, opinions and judgments which can clash with the formal nature of classroom when teaching speaking. In summary, speaking is the way to express and transfer someone's idea to others directly. suggesting the need to create a friendly and conducive environment in the classroom [3].

Conversation is one of speaking activities to express and transfer students" idea to others. Conversation is a good way to express students" idea because through conversation the students can communicate with other people. Through conversation, it lets the students to contribute in giving knowledge to the others students. Therefore, the researcher chose the conversation as the student's activities in improving their speaking skill.

The researcher found the majority of students who got problems in speaking skill and many of them were shy to speak English well. There were problems about accuracy, fluency, and comprehensibility. The students were also confused to form the words into a good sentence 
to communicate their ideas. The students didn't know how to express their ideas orally. It was difficult for the students to practice their speaking skill in the classroom. Therefore, the students were afraid of making mistakes not only to their teachers but also to their friends.

The effect of this problem was the students didn't want to express themselves in speaking English. The students had serious problem in speaking skill and it made the researcher wanted to know about their speaking skill. The researcher tried to ask the teacher of English at the eleventhgrade students. The researcher got the information that the students had problem in speaking skill especially to the eleventh-grade students. The students were really difficult to speak in English. The students didn't want to express the idea orally. The students also didn't want to practice in speaking skill. The last problem was the difficulty to speak in front of others. therefore, they didn't improve the speaking skill yet.

In improving speaking skill, teacher can use method of teaching. One of them is Cooperative Script. [4] states that Cooperative Script is a method of learning where the students work with their partner and in oral, they recapitulate parts of material that is learned. This method refers to where the students are expected to be involved actively in the speaking class activities. In the teaching and learning process the students work in pair. The students have to prepare themselves as good as possible to practice their speaking skill and teacher must give the motivation to the students, therefore students are enjoying in learning process and the become active to speak English orally.

The Concept of Speaking, speaking is giving information by speech. Through speaking people can give the information to others. According to [5], speaking is theprocess of building and sharing meaning through the use of verbal and non-verbal symbols, in variety contexts. Speaking is an essential part of beside listening, reading, and writing. Students' Speaking Achievement [6] stated that achievement is gotten after gain or reached by effort. [7] said that speaking is defined as a way to verbally communicate for mostly interpersonal and somewhat transactional purposes. According to [8], achievement is good performance that was been improved. [9] stated that achievement is the result of what an individual has learned from some educational experiences. It is important to understand that the high scores on achievement tests do not necessarily guarantee high scores on ability test and vice versa. In could be concluded that achievement in speaking skill is the important thing for the students to master in speaking English. The concept of asking and Giving Opinion, an opinion is a subjective statement or thought about an issue or topic, and the result of emotion or interpretation of fact. An opinion is supported by an argument, although people may draw opposing opinions from the same set offacts.

The Concept of Cooperative Script according to [10], Cooperative learning refers to instructional methods in which teachers organize students into small groups, which then work together to help one another learn academic content. Cooperative learning methods are extensively researched and under certain well-specified conditions they are known to substantially improve student achievement in most subjects and grade levels. Cooperative script is one of the Cooperative Learning methods. [11] stated that students working on structured cooperative scripts can learn material or procedures better than students working alone. [12] said that Cooperative Script is a method that teach the students to respect other people opinion systematically. According [13], cooperative script is one of interesting methods where the students can speak orally to their partner and they can discuss about their opinion based on the material. According to [4], the basic steps of cooperative script are as follows: a). The teacher divided the students for some groups, each group consist of twomembers. b) The teacher gives the material. C) The teacher and students decided who were the first leader and listener. d) One learner (become reader) explains what has been covered to this point, while the other (become listener) contributes by detecting and correcting errors, both learners look back through the material and make further corrections and decide on elaboration and strategies that will help them remember the key information. e). Then both learners that become reader and listener switch role. f) The teacher and students conclude the material. g) Closing, the teacher gives evaluation to the students and she or he asks the students about what is to be the difficulty of the material. According to [14], teaching defines as helping others learn to do particular things, is an everyday activity in which many people engage regularly. According to [15], there are three roles of teacher in learning activities. Theoretical framework is a chronology of the research from starting untilfinishing. It explained about connection between variables theoretically. Thus, it shows the relationship of variables in the research [16] and [17]. According to [18] and [19], hypothesis is the temporary answer ofresearch problem, till realized through the data that had been collected. In 
addition, a hypothesis is formulated in such a way that this hunch can be tested. Based upon the findings of the subsequent research, the hypothesis is supported orrejected and more hypotheses are formulated to continue the process of building a cohesive theory [20]. In this research, the researcher proposed two hypotheses namely the null hypothesis (Ho) and alternative hypothesis (Ha).

\section{METHODS}

The research method is used by researcher in collecting data. The research Improving students' speaking skill of the eleventh grade of Madrasah Aliyah Tazakka Musi Rawas Utara. In this research, the researcher used a quasi experimental method with one-group pretest-posttest design. Dealing with this method, [21] state that a quasi experimental method is to approximate the condition of all relevant variables and involve in the experiment. One Group Pre-Test Post-Test Design, where : $\mathrm{T}_{1}=$ Pre- Test, $\mathrm{X}=$ Treatment, $\mathrm{T}_{2}=$ Post- Test. The steps which were taken in doing this experiment research are as follows: 1)Surveying the related literature; 2) Identifying the research problems; 3) Formulating research hypotheses; 4) Constructing the experiments plan; 5) Collecting the data by giving the pre- test for the experimental group; 6)Treating the experimental group. 7) Collecting the data by giving the post- test for the experimental group; 8) Analyzing the data and drawing conclusion; and, 9) Writing the research report. There were two research variables in this research; they were independent variable and dependent variable. [22] stated that Independent variable is the major variable which hope investigate. [23] stated that population is any set of items, individuals, etc, which share some common observable characteristics and from which sample can be taken. [18] states that population is a set (or correlation) of all elements possessing one or more attributes of interest. The cluster random sampling is one of the techniques to choose a sample from the population. It is to choose one of sample by randomizing the group of sample [24]. Validity is the most important idea to consider when preparing or selecting an instrument for use. According to [25] validity means the degree to which a test measure what is supposed to which is intended

The independent variable of this research was "Cooperative Script" because it could influence the students"e achievement in speaking skill. The students ${ }^{\text {ee }}$ achievement in speaking skill was the independent variable because it was influenced by the dependent variable. The data obtained were analyzed through five techniques, they were: 1) individual scores, 2) conversion of individual scores, 3) normality test, 4) hypothesis testing 5) hypothesis statistics

\section{RESULTS AND DISCUSSION}

In this research, the researcher got the data obtained by giving the oral test to the eleventhgrade students of Madrasah Aliyah Tazakka Musi Rawas Utara. The number of the sample was 24 students from XI IIS 2. The data obtained had been calculated by 2 raters, the English teacher in this class as a rater I and the researcher as a rater II. The data obtained from the oral test in the pre-test and post-test were analyzed for fluency, accuracy and comprehensibility. The scores were obtained by adding the result of rater I by the rater II, and then dividing 2. After being analyzed, the researcher looked for highest score, the lowest score, and the average score of each student for pre-test and post-test.

Beside that, the data not only interpreted through the score obtained in the pre-test and post-test but also looked at the process of learning and capability of students in doing their task in this research. It is useful to know the progress of students skill. The students skill were analyzed by knowing how they couldcommunicate to the others and the students been able to express themselvesorally. There were differences of students speaking skill before and after they treated by using cooperative script. They had progress in speaking skill. More information about the findings was described below.

\section{a. The Students' Speaking Skill in the Pre-test}

Before the researcher conducted the experimental, the researcher gave students a pre-test then took studentse ${ }^{\text {ee }}$ score. The number of students who took pre-test was 24 students. When the researcher gave the pre-test to the students, most of them were difficult to start speaking english. They did not know what they want to say. They could not express their ideas in English well. They were shy to speak in english. Therefore, they could speak english well.

The result of pre-test calculation revealed that the highest score was 78 which was reached by one student and the lowest score was 33 reached by one student. Finally, it was found that the average score was 56. In the pre-test there were 7 students who were in the "satisfactory", there were 11 students who werein the "difficulty", and there were 6 students who were in the "much difficult" qualification. The following table shows the number of students in the conversion score of the pre-test.

The Number of Students

In the conversion score of the pre-test

See Heaton (1990:98 


\begin{tabular}{|c|l|c|}
\hline Rating & $\begin{array}{l}\text { Qualificati } \\
\text { on }\end{array}$ & $\begin{array}{c}\text { The Number of the } \\
\text { Students }\end{array}$ \\
\hline $\mathbf{2 6}$ & Excellent & 0 \\
\hline $\mathbf{5 . 0 - 5 . 9}$ & Very Good & 0 \\
\hline $\mathbf{4 . 0 - 4 . 9}$ & $\begin{array}{l}\text { Satisfactor } \\
\text { y }\end{array}$ & 7 \\
\hline $\mathbf{3 . 0 - 3 . 9}$ & Difficulty & 11 \\
\hline $\mathbf{2 . 0 - 2 . 9}$ & $\begin{array}{l}\text { Much } \\
\text { difficult }\end{array}$ & 6 \\
\hline $\mathbf{1 . 0 - 1 . 9}$ & $\begin{array}{l}\text { Extreme } \\
\text { difficult }\end{array}$ \\
\hline \multicolumn{2}{|l|}{ Total } & 24 \\
\hline
\end{tabular}

\section{b. The Students' Speaking Skill in the Post- Test}

The test item in the post-test was exactly same as the one that was given in the pre-test. Before the students got the test item, they were introduced about the expression of asking and giving opinion by using cooperative script in twice of treatments. After doing that, the researcher gave the students the post-test, which was included to test their expression of asking and giving opinion. When the students got the post, they were enthuisiastic and had high motivation. They wanted to try the expression. They interested to know much about English. They got good impression when they were in post test. Therefore, they were enjoyable in accomplishing the post-test.

In the post-test, the highest score was 89 reached by two students, and the lowest score was 56 reached by two students, while the average score was 70 . In the post-test there were 3 students who were in the "very good", there were 11 students who were "satisfactory", there were 9 students who were in the "difficulty", and there was 1 student who was in the "much difficult" qualification. The following table shows the number of students in the conversion score of the post-test.

The progress of pre-test and post-test result was revealed from the comparison of the students" score. In the pre-test, the highest score was 78 and thelowest score was 33 . There was one student got 33,1 student got 36,2 students got $38.5,1$ student got $41.5,1$ student got $44.5,4$ students got 50,1 student got 52.5, 1 student got 53, 2 students got 56,1 student got 58,2 students got 64,1 student got $66.5,1$ student got 69,2 students got 72,2 students got 75 , and 1 student got 78 . Therefore, Mean score in this pre-test was 56. The result was improved in post.

Based on the result of the post -test, the highest score of the speaking skill was 89 and the lowest score was 56 . There were 2 students got 56 , there were 2 students got 58.5 , there was 1 student got 61 . There were 5 students got 64 . There were 3 students got 66.5. There was 1 student got 69.5. There were 2 students got 72 . There were 1 student got 75 , there was 1 student got 78 , there were 3 studentsgot 80.5 , there was 1 student got 86 , and 2 students got 89 . Therefore, mean score of the posttest was 70 .

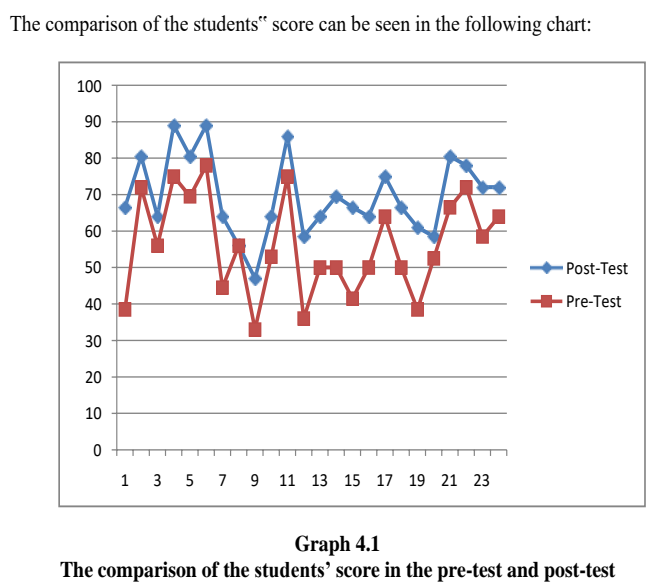

Based on the calculation above, it found out that tobtain was 11.43. So, it must be compared to the $t_{\text {table }}$ with the significance level $5 \%$ was 1.714 . So, tobtain was higher than $t_{\text {table }}(11.43>1.714)$. Based on the criteria of testing hypothesis, if $t_{\text {obtain }}$ was higher than table, it meant that Ha was accepted and automatically Ho was rejected. In the other word, improving the eleventh-grade students of Madrasah Aliyah Tazakka Musi Rawas Utara in speaking skill was significantly effective.

English is used by many countries and organization all over the world. Englis his the language used to communicate and exchange the information. English is taught in Indonesian schools. It is learned from primary school even senior high school. English subject consists of four language skills, namely listening, speaking, reading and writing.

One of the objectives in teaching English is students are able to communicate in speaking English. Speaking is one of skills in English. By speaking, students can improve their skill in communicating to another and the students are able to express themselves orally. Conversation is one of speaking activities to express and transfer students ${ }^{\text {ee }}$ idea to others. The researcher chooses the conversation as the student's activities in improving their speaking skill. According to [4], Cooperative Script is a method of learning where the students work with their partner and in oral, they recapitulate parts of material that is learned. This method refers to where the students are expected to be involved actively in the speaking class activities.

In doing the research, the researcher gave the pre-test, treatment, after that the post-test to know the student's ability in speaking skill. In addition, 
the researcher recorded the students" voices while they were doing the test orally about one until two minutes. The material of the test was the Expression of asking and giving opinion. Based on the result of the research, the researcher interpreted that after doing this research by using cooperative script in improving the eleventh-grade students in speaking skill at Madrasah Aliyah Tazakka Musi Rawas Utara, the speaking skill of the students were improved. It could be seen from the studentse $^{\text {ce }}$ average score before and after the treatment. In the pre-test, the studentse average score was 56 , and it changed to be 70 in the posttest.

In the pre-test, most of the students confused to speak English. Based on the test item which had been given to the students, they could not begin the expression of asking and giving opinion. They did not know how to start the expression of asking and giving opinion which had been given. They had problemin speaking skill because they were rarely express the ideas orally in the classroom.

Furthermore, the mean score in the post-test was 70 . The highest score was 89 achieved by two students and the lowest was 56 achieved by two students. Based on the average ability, it could be interpreted that their Skill in speaking was moderate. So, it could be concluded that there were studentse improvement inthe used of cooperative script in improving to the eleventh-grade students of Madrasah Aliyah Tazakka Musi Rawas Utara.

The effectiveness of cooperative script in improving speaking skill to the eleventh-grade students could be proved from the result of t-test calculation. In the pre-test, the students ${ }^{\text {ee }}$ average score was 56. It meant before being taught, their ability was enough difficulty. On the other hand, in the post-test, their average ability score improved to be 70 . It meant that after being taught, their average ability improving to be excellent.

In addition, [26] found the effectiveness of cooperative script in teaching through the result of the $t_{\text {-test }}$ was higher than $t_{-t a b} 1,706$. There was improving of the average score in the pre-test to post-test. In the other hand, research found that cooperative script is an effective teaching method. Cooperative Script guides the learner to independent and self-regulated competence of skills.

In this study, the researcher improved the studentse ${ }^{\text {ee }}$ speaking skill. In this case, the students had gotten the knowledge as long as they learned. They learned the meaning of the expression of asking and giving opinion. They were free to express their opinion in the test.

More important in conducting the treatment through cooperative script, the students had high motivation in learning English. They were be very interested, enthusiastic, and challenged in learning. As the result, the students ${ }^{\text {ee }}$ activeness in learning was significantly. The strengthens of Cooperative Script method were could make the students more active in speaking and also made them brave to speak English. The students could be more active because in the learning process of this method, let the students to give their opinion orally Infront of others.

Therefore, there was interaction between teacher and students by askingleading questions and providing information in order to help students discover the information they need to successfully complete a task. This information implied that students ${ }^{\text {ee }}$ academic performance improved when they could make personal connections to the skills and knowledge they were supposed to acquire.

Then, based on the result of hypothesis testing calculation showed that the $t_{\text {obtain }}$ was much higher than the $\mathrm{t}_{\text {table. The }} \mathrm{t}_{\text {obtain }}$ was 11.43 , while the $\mathrm{t}_{\text {table }}$ in the significant level $5 \%$ was 1.714 . It meant that the null hypothesis (Ho) was rejected and automatically the alternative hypothesis $(\mathrm{Ha})$ was accepted. This indicated that it was significantly effective to used Cooperative Script method in improving speaking skill to the eleventh-grade students of Madrasah Aliyah Tazakka Musi Rawas Utara.

\section{CONCLUSION}

Based on the findings presented in previous chapter, it could be concluded that there was significant difference of the speaking skill to the eleventh-grade students of Madrasah Aliyah Tazakka Musi Rawas Utara. It was proved by the difference between two means scores in the pretest and post-test. It was 14. There was improvement of the average scores or the average score from the pre-test (56) to the post-test (70). The students made progress. The progress could also be known in the student quality to be able to express their speaking skill. Before giving the treatment, many students who were frustrated and tensed to finish the expression. They felt bore and was shy to express their idea. But it changed to be full of motivation and enjoyable after researcher treated them by Cooperative Script in speaking skill.

Further more, based on hypothesis testing the researcher found that the alternative hypothesis (Ha) was accepted and the null hypothesis (Ho) was rejected since the result of the calculation of the match t-test was higher than the t-critical value. The t-obtained was 11.43, which was higher than 1.714 
as its critical value. It meant that the null hypothesis (Ho) was rejected and the alternative hypothesis (Ha) was accepted. In the other word, it was significantly effective to Cooperative Script in improving speaking skill to the eleventh grade students of Madrasah Aliyah Tazakka Musi Rawas Utara.

\section{ACKNOWLEDGMENTS}

Our deepest gratitude goes to Teachers in Madrasah Aliyah Tazakka Musi Rawas Utara, we also want to thank our boarding school friends who helped us a lot in a short time frame to complete this project.

\section{REFERENCES}

[1] H. Jeremy, "The practice of English language teaching," UK. Cambridge Univ., 2001.

[2] S. Thornbury and D. Slade, Conversation: From Description to Pedagogy. Cambridge University Press, 2006.

[3] S. Nazara, "Students' perception on EFL speaking skill development," JET (Journal English Teaching), vol. 1, no. 1, pp. 28-43, 2011.

[4] A. Suprijono, Cooperative learning: teori \& aplikasi PAIKEM. Pustaka Pelajar, 2009.

[5] A. L. Chaney and T. L. Burk, Teaching Oral Communication in Grades $K-8$. Allyn and Bacon, 1998.

[6] M. H. Manser, R. Fergusson, and D. Pickering, The Facts on File Dictionary of Proverbs. Facts On File, 2007.

[7] D. Nunan, Second Language Teaching \& Learning. Heinle \& Heinle Publishers, 1999.

[8] J. M. Echols, H. Shadily, J. T. Collins, and J. U. Wolff, An Indonesian-English Dictionary. Cornell University Press, 1989.

[9] J. F. Travers, Fundamentals of Educational Psychology. International Text Book Company, 1970.

[10] R. E. Slavin, Educational Psychology: Theory and Practice. Allyn and Bacon, 1997.
[11] A. M. O’Donnell, J. Reeve, and J. K. Smith, Educational Psychology: Reflection for Action. Wiley, 2011.

[12] D. K. Nengsih and S. Tampubolon, "Penerapan Model Pembelajaran Cooperative Script Untuk Meningkatkan Hasil Belajar Mata Pelajaran Ilmu Pengetahuan Alam Siswa Kelas V SDN Parungkuda 01 Kabupaten Sukabumi Tahun Pelajaran 2012/2013." Tersedia pada: http://ejournal. unpak. ac. id/download(Diakses 5/3/2016), 2012.

[13] S. Hamid, Investigation of Chromatin Mechanisms of Tissue-specific and Developmentally Regulated Imprinting of Gsa. University of Cambridge, 2011.

[14] D. Loewenberg Ball and F. M. Forzani, "The work of teaching and the challenge for teacher education," J. Teach. Educ., vol. 60, no. 5, pp. 497-511, 2009.

[15] A. Moore, The Good Teacher: Dominant Discourses in Teaching and Teacher Education. RoutledgeFalmer, 2004.

[16] S. Sugiyono, "Research Method Quantitative and Qualitative R\&D," Alf. Bandung, 2010.

[17] C. Narbuko and A. Achmadi, "Metodologi Penelitian, Cetakan Kesepuluh," Jakarta PT Bumi Aksara, 2009.

[18] S. Arikunto, "Prosedur penelitian: suatu pendekatan praktik. Ed. Rev," Jakarta PT Rineka Cipta, 2010.

[19] S. Torang, "Metode riset struktur dan perilaku organisasi," Bandung Alf., 2012.

[20] J. W. Best and J. V Kahn, Research in Education. Allyn and Bacon, 1993.

[21] R. Isaacs, Differential games: a mathematical theory with applications to warfare and pursuit, control and optimization. Courier Corporation, 1999.

[22] E. Hatch and H. Farhady, "Research design and statistics for applied linguistics.," 1982.

[23] L. C. Richards, "Dental attrition and craniofacial morphology in two Australian 
aboriginal populations," J. Dent. Res., vol. 64, no. 11, pp. 1311-1315, 1985.

[24] J. R. Fraenkel and N. E. Wallen, "How To Design and Evaluate Research in Education.," 1990.

[25] R. K. Heaton et al., "Reliability and validity of composite scores from the NIH Toolbox Cognition Battery in adults," J. Int. Neuropsychol. Soc. JINS, vol. 20, no. 6, p. 588, 2014.

[26] T. Anggraini, A. Tai, T. Yoshino, and T. Itani, "Antioxidative activity and catechin content of four kinds of Uncaria gambir extracts from West Sumatra, Indonesia," African J. Biochem. Res., vol. 5, no. 1, pp. 33-38, 2011. 